\title{
BIOLOGY
}

\section{Expression of cell adhesion molecules in the normal and T3 blocked development of the tadpole's kidney of Bufo arenarum (Amphibian, Anuran, Bufonidae)}

\author{
Izaguirre, MF. , García-Sancho, MN. ${ }^{\mathrm{b}}$, Miranda, LA. ${ }^{\mathrm{c}}$, Tomas, $\mathrm{J}^{\mathrm{b}}$ and Casco, VH. ${ }^{\mathrm{a}}{ }^{*}$ \\ aLaboratorio de Microscopia, Facultad de Bioingeniería, Universidad Nacional de Entre Ríos - UNER, \\ Ruta $11, \mathrm{Km} 10^{1 / 2}$, Oro Verde, Entre Ríos, Argentina \\ ${ }^{b}$ Facultat de Medicina i Ciències de Salut, Universitat Rovira i Virgili, carrer St. Llorenç num 21, 43201 Reus, España \\ 'Laboratorio de Ictiofisiología y Acuicultura, Instituto de Investigaciones Biotecnológicas, \\ Instituto Tecnológico de Chascomús CONICET-UNSAM, \\ C.C. 164 B7130IWA, Chascomús, Provincia de Buenos Aires, Argentina \\ *e-mail: vcasco@bioingenieria.edu.ar
}

Received June 19, 2006 - Accepted February 26, 2007- Distributed August 31, 2008

(With 5 figures)

\begin{abstract}
Cell adhesion molecules act as signal transducers from the extracellular environment to the cytoskeleton and the nucleus and consequently induce changes in the expression pattern of structural proteins. In this study, we showed the effect of thyroid hormone (TH) inhibition and arrest of metamorphosis on the expression of E-cadherin, $\beta$-and $\alpha$-catenin in the developing kidney of Bufo arenarum. Cell adhesion molecules have selective temporal and spatial expression during development suggesting a specific role in nephrogenesis. In order to study mechanisms controlling the expression of adhesion molecules during renal development, we blocked the $B$. arenarum metamorphosis with a goitrogenic substance that blocks TH synthesis. E-cadherin expression in the proximal tubules is independent of thyroid control. However, the blockage of TH synthesis causes up-regulation of E-cadherin in the collecting ducts, the distal tubules and the glomeruli. The expression of $\beta$-and $\alpha$-catenin in the collecting ducts, the distal tubules, the glomeruli and the mesonephric mesenchyme is independent of TH. TH blockage causes up-regulation of $\beta$-and $\alpha$-catenin in the proximal tubules. In contrast to E-cadherin, the expression of the desmosomal cadherin desmoglein 1 (Dsg-1) is absent in the control of the larvae kidney during metamorphosis and is expressed in some interstitial cells in the $\mathrm{KClO}_{4}$ treated larvae. According to this work, the Dsg-1 expression is down-regulated by TH. We demonstrated that the expression of E-cadherin, Dsg-1, $\beta$-catenin and $\alpha$-catenin are differentially affected by TH levels, suggesting a hormone-dependent role of these proteins in the B. arenarum renal metamorphosis.
\end{abstract}

Keywords: catenins, cadherins, metamorphosis, amphibians.

\section{Expressão das moléculas de adesão celular no desenvolvimento normal e com a inibição do hormônio tireoidea do rim nas larvas do Bufo arenarum (Amphibia, Anura, Bufonidae)}

\begin{abstract}
Resumo
Moléculas de adesão celular atuam como tradutores do ambiente extracelular para o citoesqueleto e o núcleo e, conseqüentemente, induzindo mudanças no padrão da expressão das proteínas estruturais. Neste estudo, observamos os efeitos da inibição do hormônio tireóidea (TH) e detenção da metamorfose na expressão da E-caderina, $\beta$ - e $\alpha$ - catenina no desenvolvimento do rim do Bufo arenarum. As moléculas de adesão celular durante o desenvolvimento têm uma expressão temporal e espacial seletiva, sugerindo um papel específico na nefrogênese. Com o propósito de estudar os mecanismos de controle da expressão das moléculas de adesão durante o desenvolvimento renal, bloqueou-se a metamorfose do B. arenarum com uma substancia goitrogênica que bloqueia a síntese de TH. A expressão da E-caderina nos tubos proximais é independente do controle da tireóide. Entretanto, o bloqueio da síntese de TH provoca uma sobre elevação da E-caderina nos dutos coletores, nos tubos distais e nos glomérulos. A expressão da $\beta$ - e $\alpha$-catenina nos dutos coletores, nos tubos distais, nos glomérulos e no mesênquima mesonéfrico é independente da TH. O bloqueio da TH causa uma sobre-regulação da $\beta$ - e $\alpha$-catenina nos tubos proximais. Em contraste com a E-caderina, a expressão da caderina desmossomal demogloína 1 (Dsg-1) é ausente no controle durante a metamorfose da fase larval dos rins e se expressa em algumas células intersticiais nas larvas tratadas com $\mathrm{KClO}_{4}$. De acordo com este trabalho, a expressão Dsg-1 é subregulada pela TH. Demonstramos que a expressão da E-caderina, Dsg-1, $\beta$-catenina e $\alpha$-catenina são afetadas de forma diferencial pelos níveis de TH, sugerindo um dependência hormonal destas proteínas na metamorfose renal do B. arenarum.
\end{abstract}

Palavras-chave: cateninas, cadherinas, metamorfose, anfíbios 


\section{Introduction}

During metamorphosis, the effective transition from tadpole to froglets depends on the coordinated changes that occur in each developing organ (Dodd and Dodd, 1976). Within each organ, different tissues experience temporally regulated and specific transformations (Dodd and Dodd, 1976; Gilbert and Frieden, 1981; Fox, 1983; Balls and Bownes, 1985). The embryonic kidney is a classic developmental model for studying inductive tissue interactions, which regulate the organogenesis (Kispert et al., 1998).

As in fishes, the larval anuran kidney is the pronephros. It functions primarily in the excretion of water and ammonia. Pronephros forms from the anterior nephrostomes and persists throughout larval life only to regress and disappear by the end of metamorphosis (Duellman and Trueb, 1994). Pronephric growth and differentiation is mainly controlled by circulating thyroid hormones. It is functional during the early amphibian larval stages, but it is then replaced by the mesonephros, the anuran adult kidney (Niewkoop and Faber, 1994). Structurally, the pronephros is a tightly arranged mass of tubules with ciliated nephrostomial ducts leading to the coelom. In general, anurans have three nephrostomial tubules, which join to form a common tubule, the Wolffian duct. Evaginations of the dorsal aorta form paired glomeruli, which are partially surrounded by outpocketing of the nephrostomial ducts (Bowman's capsules). In anurans only the nephrostomal tissues persist (Duellman and Trueb, 1994). In the mesonephric kidneys the tubular connections with the coelom have been lost, and glomeruli are contained within the Bowman's capsule (Duellman and Trueb, 1994). The kidney changes are controlled by the proliferation and differentiation of the parenchymal cells and the extracellular matrix and by elimination of larval cell types through programmed cell death. Some larval cells are reprogrammed to become adult types. The cell replacements depend on interactions among different cells and between cells and its extracellular matrix. The main cell adhesion molecules involved in vertebrate morphogenesis are the cadherins (Takeichi, 1988). Classical and non-classical cadherins belong to a superfamily of $\mathrm{Ca}^{+2}$-dependent cell adhesion molecules (Takeichi, 1988, 1991; Pouliot, 1992), and are associated with cytoplasmic proteins named catenins (Hirano et al., 1987; Ozawa et al., 1989; Nagafuchi and Takeichi, 1989; Stappert and Kemler, 1993; Wheelock et al., 1996; Wahl et al., 1996). The best characterized catenins are $\alpha$-, $\beta$ - and $\gamma$-catenin (Herrenknecht et al., 1991; Nagafuchi et al., 1991; McCrea et al., 1991; Peifer et al., 1992; Butz et al., 1992; Piepenhagen and Nelson, 1993). The adhesion strength in some tissues also depends on the co-expression of other cell adhesion molecules, including the neural cell adhesion molecule (NCAM), a member of the immunoglobulin superfamily of $\mathrm{Ca}^{+2}$ independent cell adhesion molecules (Rutishauser, 1984; Cunningham et al., 1987).
Amphibian metamorphosis is mainly regulated by TH (Kendall, 1915, 1919; Leloup and Buscaglia, 1977; White and Nicoll, 1981) and is sensitive to environmental factors such as temperature, water availability, crowding, light, diet, and environmental iodine levels (Dodd and Dodd, 1976). Amphibian larvae respond to alterations in these factors by changes in the developmental phenotypes (Stearns, 1989). Thyroxine and triiodothyronine levels in the normal tadpoles remain low during pre- and pro-metamorphosis, but increase around the onset of metamorphic climax (White and Nicoll, 1981; Suzuki and Suzuki, 1981). Thyroidectomy and chemical inhibitors (goitrogens), including thiouracil, thiourea, sulfonamides, thiocyanate, potassium perchlorate, and methimazole (Dodd and Dodd, 1976; Brown, 1997) can block metamorphosis (Dodd and Dodd, 1976). In this study, we determined the TH influence on the expression of cell adhesion molecules during the development of the larval kidney of $B$. arenarum. We blocked normal metamorphosis with potassium perchlorate $\left(\mathrm{KClO}_{4}\right)$ and the expression of cell adhesion molecules during kidney development was examined.

\section{Material and Methods}

\subsection{Toad embryos}

Eggs production was induced in the adult females of Bufo arenarum (Hensel) 1867, (provided by La Cucha Co, Bs. As.) by injection of homologous pituitary gland suspension. Embryos were obtained by artificial fertilization, mixing eggs with minced testicular tissue (Rengel et al., 1988), and cultured in Holtfreter's solution (Holtfreter, 1931).

\subsection{TH synthesis blockage}

After hatching, larvae were kept at a density of 10 per liter, for three months in dechlorinated water with $0.034 \% \mathrm{KClO}_{4}$ solution at $18 \pm 2{ }^{\circ} \mathrm{C}$ with $12 \mathrm{~L}: 12 \mathrm{D}$ photoperiod (Miranda et al., 1992). The $\mathrm{KClO}_{4}$ solution was renewed once a week. Control larvae were kept under the same conditions but in tap water. Tadpoles were fed with boiled lettuce. Metamorphic stages used in this study were determined by Martin's table (Martin et al., 1985).

\subsection{Morphology and immunohistochemistry}

Five control larvae at stages VIII and XX, and five $\mathrm{KClO}_{4}$-treated larvae arrested at stage VIII were processed for immunohistochemical studies. All animals were fixed in Bouin's liquid (15:4:1 of picric acid saturated solution, formaldehyde $40 \%$ and acetic acid) or Carnoy's solution (6:3:1 of ethanol, chloroform and acetic acid) for 2 hours at $20{ }^{\circ} \mathrm{C}$, dehydrated in ethanol and embedded in paraffin. Sagital $5 \mu \mathrm{m}$-thick sections were obtained in a Reichert Jung Hn 40 microtome and dried onto $1 \%$ gelatin coated glass slides. Mouse monoclonal antibodies to E-cadherin (clone 36 mouse IgG2a), to $\beta$-catenin (clone 1a mouse $\operatorname{IgG} 1$ ) and to $\alpha$-catenin (clone 5 mouse IgG1) (Transduction Labs, Lexington, 
KY), were used at a 1:50 dilution in phosphate buffer saline (PBS). Antibodies to cadherin-5, P-cadherin, desmoglein, $\gamma$-catenin and pp120 were purchased as a cell adhesion sampler kit (Transduction Labs, Lexington, $\mathrm{KY}$ ) and used at 1:50 and 1:100 dilutions. The monoclonal antibody 13A9, a mouse $\mathrm{IgG} 1$ that recognizes N-cadherin from different species, was used at a 1:50 dilution (Knudsen et al., 1995). The monoclonal antibody 4d, a mouse IgG1 (chicken, frog) directed to $180 \mathrm{kDa}$ N-CAM polypeptide (cytoplasmic domain) was developed in Dr. Rutishauser's lab (Dep. of Genetics, Case Western Reserve Univ., Cleveland OH, USA), and was purchased from the Developmental Studies Hybridoma Bank (Dept. of Pharmacology and Mol. Sci., Johns Hopkins Univ. School of Medicine, Baltimore, MD and Dept. of Biol. Sci., Univ. of Iowa, Iowa City, IA). These antibodies have been previously shown to recognize anuran species (Izaguirre et al., 2000; 2001a, 2001b; Casco et al., 2000, and unpublished results for P-cadherin and $\gamma$-catenin). Normal horse serum (Vector Laboratories Inc., Burlingame, California, USA) was used as negative control. Sections from $B$. arenarum tadpoles were dewaxed, rehydrated and permeated with 0.1\% Triton X-100 (Sigma, St. Louis, MO.) in PBS for 15 minutes. Sections were incubated in normal horse serum for 30 minutes followed by overnight incubations with the primary antibodies at $4{ }^{\circ} \mathrm{C}$ in a humid chamber, rinsed in PBS and incubated with species-specific biotinylated secondary antibodies diluted 1:400 in PBS containing $1 \%$ BSA and 2\% normal horse serum. After rinsing in PBS, sections were incubated with avidin-biotin complex and 3, 3' diaminobenzidine substrate (ABC kit Vectastain Elite ${ }^{\circledR}$, Vector Burlingame, CA). Slides were mounted with Canada balsam (Biopack ${ }^{\circledR}$, Buenos Aires, Argentina). In the control sections, primary antibodies were replaced with horse non-immune serum (Sigma, St Louis, MO). Sections were examined and photographed with a BX 50 Olympus microscope.

For the morphological analysis, sagittal $5 \mu \mathrm{m}$-thick sections were dewaxed, rehydrated and stained with hematoxilin-eosin (HE).

\section{Results}

\subsection{Bufo arenarum kidney morphogenesis}

The kidney morphogenesis of Bufo arenarum is very similar to other anurans (Rugh, 1951; Duellman and Trueb, 1994; Møbjerg et al., 2000). In Bufo arenarum, this process starts at the tail bud stage. The pronephros is complete at stage I and the mesonephric kidney develops rapidly and takes over the increasingly important excretory functions.

Bufo arenarum larvae of stage VIII have paired kidneys which are located retroperitoneally and consist of two cranial pronephros, situated behind the gill region, and caudally placed two elongated mesonephros.

The mesonephros present in some regions developed nephrons, conformed by Malpighian corpuscles (glomerulus) surrounded by the Bowman's capsule and, proximal and distal tubule (Figures 1a-d). Also it has developing tubules as abundant masses of cells (undifferentiated mesonephrogenic mesenchyme) differentiate into tubules that open into the collecting duct system (Figure 1d).

The proximal tubule consists of cylindrical to height cuboidal cells, frequently denominated prismatic cells, and with high brush border (Figures 1a-d). These tubules have a dirty lumen. The distal tubule consists of cubic cells with a generally apical nucleus (Figures 1a,c). The collecting ducts exhibit an enlarged lumen with an undu-
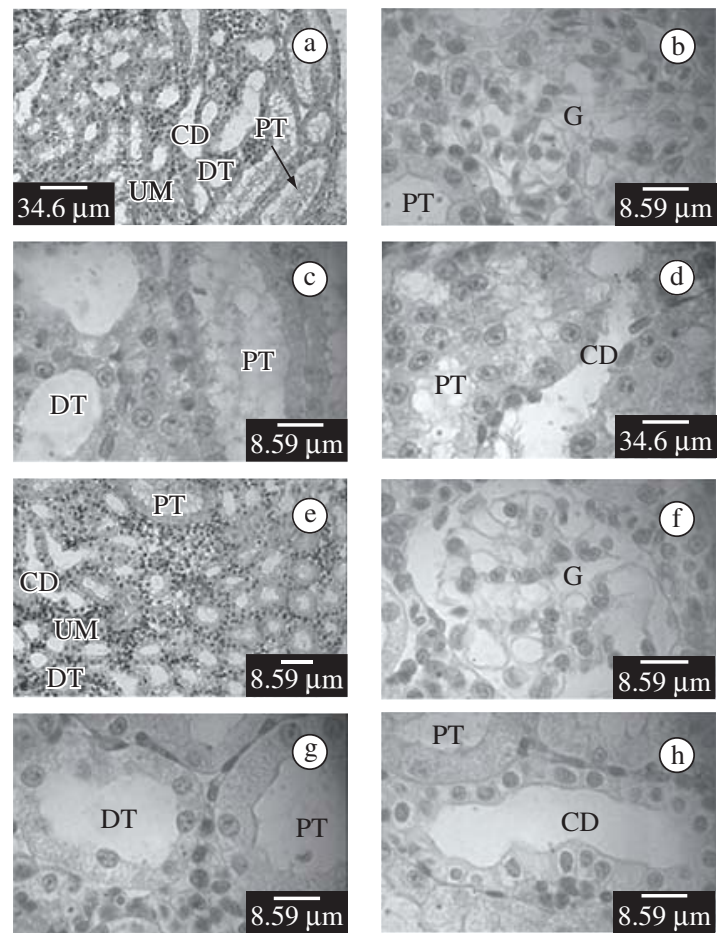

Figure 1. a-d) Sagital section of the control and e-h) $\mathrm{KClO}_{4}$ treated of the B. arenarum stage VIII larvae at mesonephros level, HE. a) Panoramic view, showing nephrons differentiate into the renal corpuscles, proximal and distal tubules, and collecting ducts. There are abundant undifferentiated mesonephrogenic mesenchyme. b) Detail of the glomerulus. c) Detail of the proximal and distal tubules. Proximal tubule consists of prismatic cells and a dirty lumen. Distal tubule consists of cubic cells with an apical generally nucleus. Note cell mass undifferentiated mesonephric mesenchymal. d) Detail of the proximal tubule and the collecting duct. The collecting duct exhibits an enlarged lumen with an undulated surface. e) Panoramic view, showing undifferentiated mesonephrogenic mesenchyme and nephrons differentiate into renal corpuscles, proximal and distal tubules, and collecting ducts. f) Detail of the glomerulus. g) Detail of the proximal and distal tubules, and the undifferentiated mesonephric mesenchymal cells. and h) Detail of the proximal tubule and the collecting duct. PT: proximal tubule; DT: distal tubule; CD: collecting duct; G: glomerulus; UM: undifferentiated mesenchyma. 
lated surface. The epithelium is composed of light and dark cells of variable shape (Figures 1a,d).

Mesonephros of $\mathrm{KCLO}_{4}$-treated larvae of stage VIII present similar morphologic features to the control larvae of stage VIII (Figures 1e-h).

Mesonephros of control larvae of stage XX present abundant differentiated nephrons (not shown).

Expression of cell adhesion molecules in the normal and T3 blocked development of the tadpole's kidney of Bufo arenarum.

We compared the expression of different cell adhesion molecules in the kidney of the control and $\mathrm{KClO}_{4}$ treated larvae of B. arenarum. Larvae treated with $\mathrm{KClO}_{4}$ solution for three months halted their development at the pre-metamorphic stage VIII (Figures 2a-b), without altering body growth. Control larvae completed metamorphosis (stage XX) after three months (Figures 2c). The expression of cell adhesion molecules was examined. Fixation in both fixatives, Bouin's liquid and Carnoy's solution, produced the same results.

\subsection{Expression of E-cadherin and desmoglein}

In stage VIII of the control larvae of B. arenarum, strong E-cadherin immunoreactivity is detected on the cell surface of the developing mesonephros proximal tubules (Figures 3a) and a weak immunoreactivity is detected in the collecting ducts and in few undifferentiated mesonephrogenic mesenchymal cells (Figures 3b-c). E-cadherin is not detected in the distal tubules and the developing glomerulus (Figure 3b). In stage VIII-arrested larvae treated with $\mathrm{KClO} 4$, E-cadherin expression in the proximal tubules and undifferentiated mesenchymal cells (Figures 3d vs. 3a-b) is similar to the controls. However, E-cadherin expression increases in the collecting ducts and is present in some glomerular cells, and in the distal tubules at low levels (Figures $3 \mathrm{~d}-\mathrm{f}$ versus $3 \mathrm{~b}-\mathrm{c}$ ). The number of E-cadherin-positive tubules is higher after
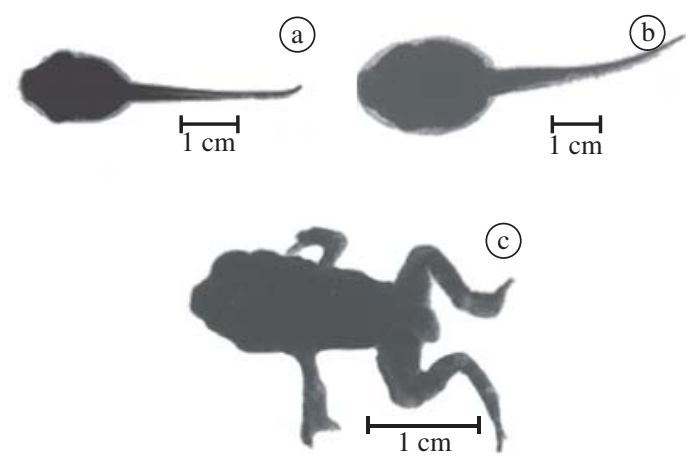

Figure 2. The Bufo arenarum larvae. a) Control larvae at stage VIII b) KClO4-treated larvae at three months of bioassay. Larvae halted their development but not their body growth, at premetamorphic stage VIII. c) Control larvae at stage $\mathrm{XX}$, at the end of metamorphosis. goitrogen-treatment than in the control larvae (Figures $3 \mathrm{~g}, \mathrm{~h})$ (Table 1).

Desmoglein-1 molecule is absent in the control larvae kidney during metamorphosis, but it is present in some interstitial cells only in the $\mathrm{KClO}_{4}$ treated larvae (Figure 4a) (Table 1).

\subsection{Expression of $\beta$ - and $\alpha$-catenin}

In stage VIII control larvae $\beta$-catenin is detected in the plasma membrane in few mesonephric distal tubules and in the collecting ducts (Figures $4 \mathrm{~b}-\mathrm{c}$ ). Furthermore, $\alpha$-catenin is detected in the mesonephros collecting ducts and the proximal and distal tubules (Figure 4d).
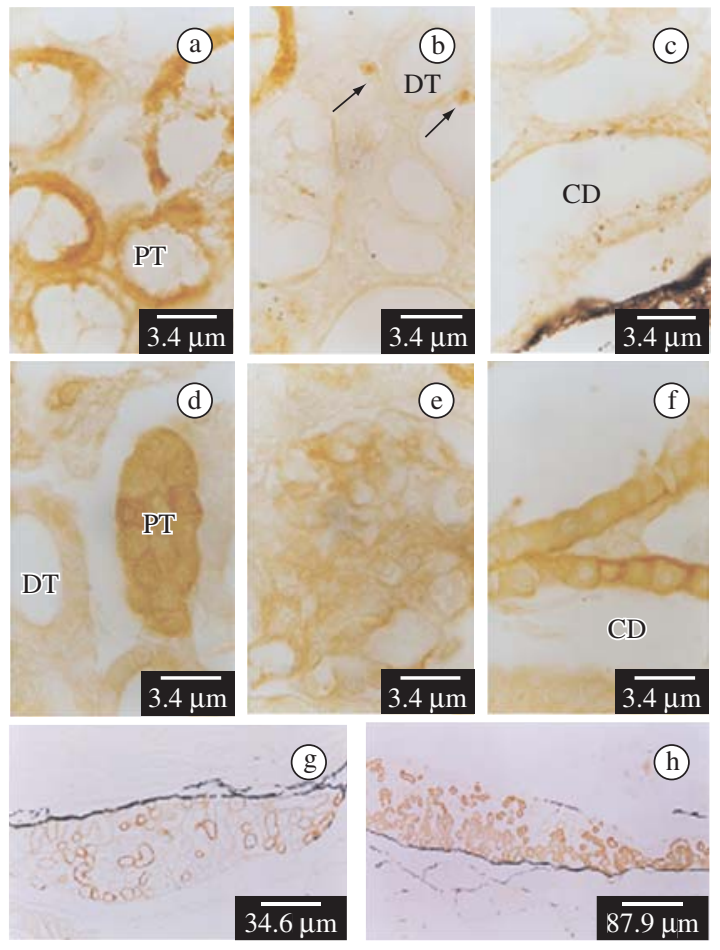

Figure 3. a-c and g) Sagittal section of control and d-f and h) $\mathrm{KClO} 4$-treated of the $B$. arenarum stage VIII larvae at mesonephros level, showing E-cadherin expression. a) Strong signal on cell surface of the proximal tubules. The proximal tubule consists of prismatic cells and a dirty lumen. b) Scarce cells of undifferentiated mesonephrogenic mesenchyme immunopositive (arrows), and distal tubules and glomerulus immunonegative. The distal tubule consists of cubic cells with a generally apical nucleus. c) A light signal was localized in the collecting ducts. The collecting ducts exhibit an enlarged lumen with an undulated surface. d) Strong label on the proximal tubules and undifferentiated mesenchymal (arrow) and apparition on distal tubules at very low levels. e) A clear label was observed in some glomerulus cells. f) The E-cadherin expression increase in the collecting ducts. g) versus $h$ ) Increase of the labeled tubules number after goitrogen-treatment. PT: proximal tubule; DT: distal tubule; CD: collecting duct; G: glomerulus. 
Table 1. Cell adhesion molecules expression in the control and $\mathrm{KClO}_{4}$ treated B. arenarum larvae.

\begin{tabular}{|c|c|c|c|}
\hline B. arenarum larvae & Stage VIII & Stage VIII & Stage XX \\
\hline Antibodies & Control & $\mathrm{KClO}_{4}$ treated & Control \\
\hline Anti-E-cadherin & $\begin{array}{l}\text { ++++ proximal tubules } \\
++ \text { undifferentiated } \\
\text { mesonephrogenic mesen- } \\
\text { chyme + collecting ducts } \\
\text { - distal tubules } \\
\text { - glomerulus }\end{array}$ & $\begin{array}{l}++++ \text { proximal tubules } \\
++ \text { undifferentiated mes- } \\
\text { onephrogenic mesenchyme } \\
++++ \text { collecting ducts } \\
+ \text { glomerulus and distal } \\
\text { tubules }\end{array}$ & $\begin{array}{l}++++ \text { proximal, } \\
\text { distal and collecting tubules } \\
- \text { glomerulus }\end{array}$ \\
\hline Anti-desmoglein & - & ++++ interstitial cells & - \\
\hline Anti-P-cadherin & - & - & - \\
\hline Anti-N-cadherin & - & - & - \\
\hline Anti-cadherin-5 & - & - & - \\
\hline Anti-NCAM 180 & - & - & - \\
\hline Anti- $\beta$ catenin & $\begin{array}{l}+ \text { distal tubules } \\
++++ \text { collecting ducts } \\
- \text { glomerulus }\end{array}$ & $\begin{array}{l}\text { + distal tubules } \\
++++ \text { collecting tubules } \\
+++ \text { proximal tubules } \\
\text { - glomerulus }\end{array}$ & $\begin{array}{l}+ \text { distal tubules } \\
++++ \text { collecting and } \\
\text { proximal tubules } \\
\text { - glomerulus }\end{array}$ \\
\hline Anti- $\alpha$ catenin & $\begin{array}{l}++++/+++ \text { collecting and } \\
\text { distal tubules } \\
+ \text { proximal tubules } \\
- \text { glomerulus }\end{array}$ & $\begin{array}{l}++++/+++ \text { collecting and } \\
\text { distal tubules } \\
+ \text { proximal tubules } \\
\text { - glomerulus }\end{array}$ & $\begin{array}{l}++++/+++ \text { collecting, } \\
\text { proximal and distal tubules } \\
- \text { glomerulus }\end{array}$ \\
\hline Anti- $\gamma$ catenin & - & - & - \\
\hline Anti - pp120 & - & - & - \\
\hline
\end{tabular}

Signal strength. Very strong: ++++; Strong: +++; Moderate ++; Low: +; Non detectable: -.

In the $\mathrm{KClO}_{4}$-treated larvae $\beta$-catenin is expressed not only in the distal tubules and the collecting ducts but also in the proximal tubules (Figures 4e-f), co-expressed with E-cadherin throughout the entire nephron (Figures $3 \mathrm{~d}-\mathrm{f}$ and $4 \mathrm{e}-\mathrm{f}$ ). $\alpha$-catenin is expressed in the proximal and distal tubules and the collecting ducts, coexpressed with E-cadherin and $\beta$-catenin (not shown) (Table 1). $\beta$-Catenin and $\alpha$-catenin are not detected in the glomeruli.

\subsection{Expression of E-cadherin, desmoglein, $\beta$ - and} $\alpha$-catenin in the kidney at the end of metamorphosis

At stage XX control, E-cadherin expression is detected in both cell membrane and cytoplasm of the proximal and distal tubules and in the collecting ducts (Figures 5a-b). $\beta$ - and $\alpha$-catenin are co-localized with E-cadherin in distal and proximal tubules and in collecting ducts (Figures 5c-f) Table 1). Neither E-cadherin, $\beta$-nor $\alpha$-catenin are found in the glomeruli. Desmoglein-1 is not detected in any structures at this stage.

Other cell adhesion molecules expression in the developing kidney

N-CAM-180, N-cadherin, P-cadherin, cadherin-5, pp120 and $\gamma$-catenin are not detected neither in the treated nor control kidneys (Table 1).

\section{Discussion}

During vertebrate development, the kidney develops in three forms, pronephros, mesonephros and metanephros. The metanephros, which constitutes the adult kidney of reptiles, birds and mammals, is not present in fish or in amphibians. Although these renal systems differ in complexity; they have the nephron as the basic functional unit (Goodrich, 1958; Saxén, 1987). In amphibians the pronephros is functional during the larval stages. The mesonephros begins to develop at the 8 to $10 \mathrm{~mm}$ larval stage, persists and becomes fully formed and is functional by the time of metamorphosis, ready to assume the increased excretory load of a terrestrial organism (Rugh, 1951). During prometamorphosis, the pronephros and the developing mesonephros work simultaneously.

In this study, we examined the expression of cell adhesion molecules in the developing kidney of $B$. arenarum, a common toad that occurs in the south of South America, and also in animals under treatment with a goitrogenic substance, which blocks TH synthesis.

E-cadherin expression pattern changes from stage VIII to stage $\mathrm{XX}$, increasing in the collecting ducts, appearing in the distal tubules and disappearing from the mesonephric mesenchyme. E-cadherin expression re- 

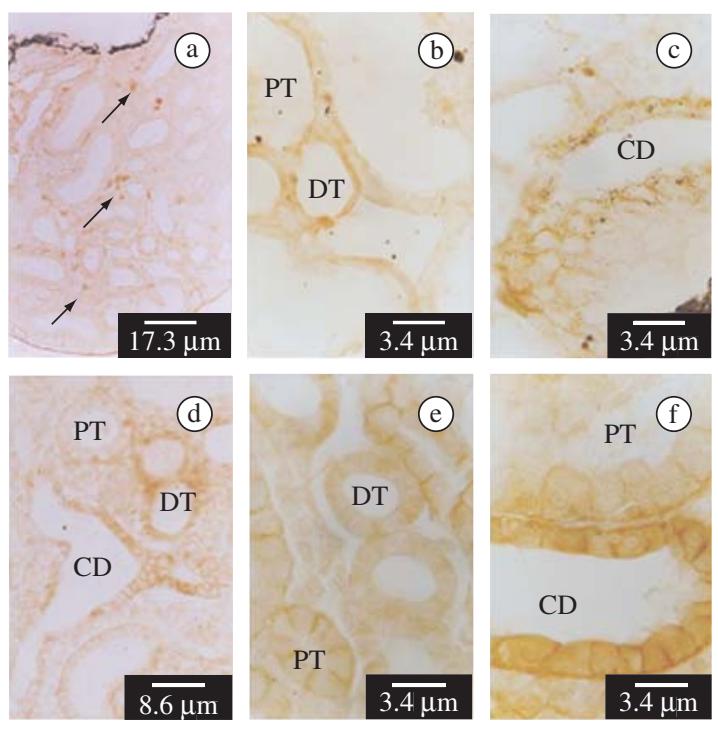

Figure 4. b-d) Sagittal section of the control and a, e-f) $\mathrm{KClO}_{4}$-treated of the $B$. arenarum stage VIII larvae at mesonephros level, showing desmoglein, $\beta$ - and $\alpha$-catenin expression. a) Desmoglein was detected only in interstitial cells of treated larvae. b) Light signal of $\beta$-catenin on the cell plasma membranes of the distal tubules. c) Intense $\beta$-catenin expression in the collecting ducts. d) $\alpha$-catenin expression in the collecting ducts and in the proximal and distal tubules. e) $\beta$-catenin is expressed on the distal and proximal tubules. f) The collecting ducts exhibit a strong $\beta$-catenin expression. PT: proximal tubule; DT: distal tubule; CD: collecting duct.

mains unchanged in the proximal tubule during development. TH inhibition with potassium perchlorate did not affect the expression of E-cadherin in the proximal tubules, but it down-regulates E-cadherin expression in the distal and collecting tubules during premetamorphosis. However, towards the metamorphic climax TH seems to exert an up regulation over collecting and distal tubules.

$\beta$-catenin and $\alpha$-catenin expression were differentially controlled by $\mathrm{TH}$ in the proximal tubules but not in the collecting and distal tubules. During premetamorphosis, $\beta$-catenin and $\alpha$-catenin expression both in the collecting and distal tubules, in the glomerulus and the mesonephric mesenchyme seem to be T3-independent, but this hormone exerts a down regulation in the proximal tubules. At the end of metamorphosis (stage XX), catenins were found co-expressed with E-cadherin in all renal tubules, suggesting maturation of cadherin-catenin junction complexes.

In contrast to the premetamorphic kidney of the $B$. arenarum tadpoles, in the human kidney, E-cadherin is firstly expressed in the branching ureteral bud (Vestweber et al., 1985), but is not detected in either induced or non-induced mesenchyme, and is detected in comma- and S-shaped bodies. Later, it appears in the proximal and distal tubules, but is never expressed in
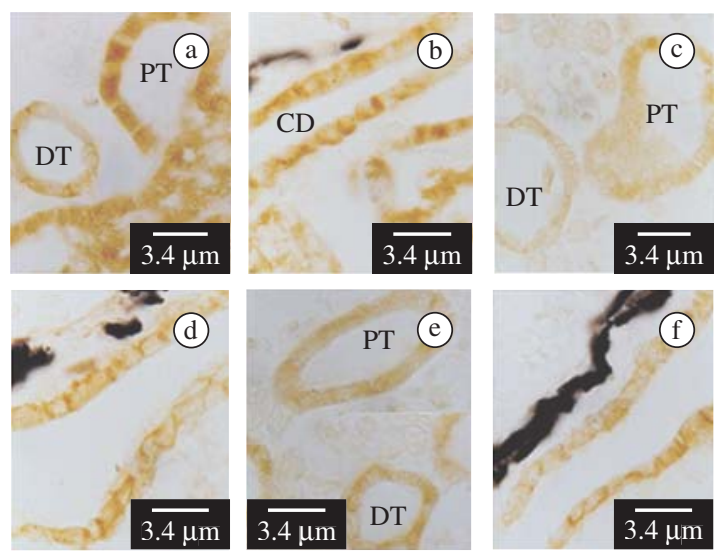

Figure 5. Sagittal section of control of the B. arenarum stage $\mathrm{XX}$ larvae at mesonephros level, showing E-cadherin $\mathrm{a}-\mathrm{b}$ ), $\beta$ - c-d) and $\alpha$-catenin e-f) expression. $a-b)$ Note E-cadherin expression at intercellular and cytoplasmic level both on the proximal and distal (insert) tubules, as on the collecting ducts, respectively. c-d) $\beta$-catenin expression in the distal and proximal tubules, and the collecting ducts respectively. e-f) $\alpha$-catenin expression in the distal (insert) and proximal tubules, and the collecting ducts, respectively. PT: proximal tubule; DT: distal tubule; CD: collecting duct.

the glomerular structures. In the adult human kidney, the expression is comparable to that observed during development. E-cadherin is weakly expressed in the proximal and distal tubules and is strongly expressed in the collecting ducts (Perantoni, 1999). In rats, E-cadherin is abundant in the distal tubule, the collecting duct and most medullar segments, but is present only at very low levels in the proximal tubules (Prozialeck et al., 2004). At the end of metamorphosis of B. arenarum, E-cadherin is absent in the glomerulus, like in the human kidney, but is strongly expressed in the proximal and distal tubules and the collecting ducts, indicating a differential role of this molecule in amphibian and mammalian kidneys.

To examine the role of E-cadherin role during renal morphogenesis, blocking antibodies had been used in explanted cultures of renal primordia (Vesteweber et al., 1985; Klein et al., 1988) and in the cultured MadinDarby canine kidney (MDCK) cells (Gumbiner et al., 1988; Behrens et al., 1989). In renal primordial cultures anti-E-cadherin antibodies failed to inhibit normal morphogenesis, but they blocked the cell adhesion in MDCK cells (Gumbiner et al., 1988; Behrens et al., 1989). E-cadherin knockout models affect embryogenesis prior to implantation preventing the study of E-cadherin in the renal morphogenesis (Larue et al., 1994; Riethmacher et al., 1995; Izaguirre et al., 2001b). In contrast to mammalian kidneys where $\mathrm{N}$ - and P-cadherin are expressed (Biddlestone and Fleming 1991; Wu et al., 1993; Nouwen et al., 1993; Tassin et al., 1994; Tani et al., 1995; Perantoni, 1999; Prozialeck et al., 2004), we did not find $\mathrm{N}$ - or P-cadherin in the $B$. arenarum kidney, although the antibodies used have cross-reactivity with anurans 
(Izaguirre et al., 2000; 2001a; for P-cadherin results not published).

Interestingly, desmoglein is not present during renal development, but is strongly expressed in the mesonephric mesenchymal cells when TH and metamorphosis was blocked. These results suggest that desmoglein is THdown regulated during renal development. Desmoglein 1 and $2 / 3$ are found in induced mesenchyme of human and mouse kidneys and persist through tubulogenesis, although its expression becomes restricted, forming a ring around cells (Garrod and Fleming, 1990). Presumptive glomerular epithelia are also immunoreactive, but this is lost from the podocytes with maturation. In general, desmosomes are small during development but they enlarge as the kidney matures (Perantoni, 1999).

In mammals $\mathrm{N}-\mathrm{CAM}$ seems to have a minor role in renal development and maintenance, but it appears to play a significant role in inflammatory processes affecting the kidney. N-CAM appears in early development between induced and non-induced mesenchymal cells, but is rapidly lost from polarized epithelia. Its expression is retained by stromal populations into later stages; however, in the adult kidney, no cells expressed N-CAM, except for interstitial nerve fibers and nerves, which were strongly positive (Klein et al., 1988; Lackie et al., 1990; Nouwen et al., 1993). N-CAM-180 was not detected in the $B$. arenarum kidney (Izaguirre et al., 2000).

Several studies, including the present work, demonstrate that a variety of cadherins are present in the kidney and are differentially expressed in various segments of the nephron (Vestweber et al., 1985; Biddlestone and Fleming 1991; Wu et al., 1993; Nouwen et al., 1993; Tassin et al., 1994; Tani et al., 1995; Perantoni, 1999; Shimazui et al., 2000; Prozialeck et al., 2004). Furthermore, each cell adhesion molecule may have a differential pattern of expression in several segments suggesting specific roles during kidney development. These results raise the possibility that differences in cadherin and catenin expression levels and localization may contribute to the difference in the susceptibility of various nephron segments to renal pathology or nephrotoxic injury. It is known that $\mathrm{TH}$ is responsible for increase in both the active and passive transport of $\mathrm{NaCl}$ in the proximal straight tube (Shah et al., 2000), leading to the deterioration of a previously impaired renal function (Makino et al., 2000).

It is known that TH regulates NCAM expression in the nervous system and skeletal muscle during metamorphosis (Levi et al., 1990). However, direct demonstration of the effect of TH on the expression of other cell adhesion molecules is limited (Becker et al., 1994; Laslett et al., 2000; Luegmayr et al., 2000). This paper shows for the first time the TH effect on the distribution and expression of cadherin and catenin cell adhesion molecules in the $B$. arenarum developing kidney. Our data demonstrate temporal and spatial control of E-cadherin, desmoglein, $\beta$ - and $\alpha$-catenin, by TH during $B$. arenarum kidney development.
Acknowledgements - This work was supported by a grant from SCYTFRH-UNER, PID 6053-1 (to VHC) and in part by the School of Medicine of Rovira and Virgili University, and the IIB/INTECH of Argentina.

\section{References}

BALLS, M. and BOWNES, M., 1985. Metamorphosis. USA: Oxford University Press.

BECKER, CG., BECKER, T., SCHMIDT, A., and ROTH, G., 1994. Polysialic acid expression in the salamander retina is inducible by thyroxine. Dev. Brain Res., vol. 79, no. 1, p. $140-146$

BEHRENS, J., MAREEL, MM., VAN ROY, FM., and BIRCHMEIER, W., 1989. Dissecting tumor cell invasion: epithelial cells acquire invasive properties after the loss of uvomorulin-mediated cell-cell adhesion. J. Cell Biol., vol. 108, no. 6 , p. $2435-2447$.

BIDDLESTONE, LR. and FLEMING, S., 1991. Morphological evidence that A-CAM is a major intercellular adhesion molecule in human kidney. J. Pathol., vol. 164, no. 1, p. 9-15.

BROWN, DD., 1997. The role of thyroid hormone in zebrafish and axolotl development. Proc. Natl. Acad. Sci. USA, vol. 94, no. 24 , p. $13011-13016$

BUTZ, S., STAPPERT, J., WEISSIG, H. and KEMLER, R., 1992. Plakoglobin and $\beta$-catenin: distinct but closely related. Science, vol. 257, no. 5073, p. 1142-1144.

CASCO, VH., IZAGUIRRE, MF., PERAlTA SOLER, A. and PAZ, DA., 2000. Expression of Polysialic Acid, $\alpha$ - and $\beta$-Catenins in Adult Toad Testis in Hibernation Stage and After Gonadotrophin-Releasing Hormone (GnRH) Treatment. Eur. J. Morphol., vol. 38, no. 3., p. 167-175.

CUNNINGHAM, BA., HEMPERLY, JJ., MURRAY, BA., PREDIGER, EA., BRACKENVURY, R., EDELMAN, GM., 1987. Neural cell adhesion molecule: structure, immunoglobulinlike domains, cell surface modulation, and alternative RNA splicing. Science, vol. 236, no. 4803, p. 799-806.

DODD, MHI. and DODD, JM., 1976. The biology of metamorphosis. In Lofts, B. (Ed.). Physiology of the Amphibia. New York: Academic Press. 599, p. vol. 3.

DUELLMAN, WE. and TRUEB, L., 1994. Metamorphosis. In Biology of amphibians. USA: The Johns Hopkins University Press.

FOX, H., 1983. Amphibian morphogenesis. New Jersey, Clifton, USA: Humana Press.

GARROD, DR. and FLEMING, S., 1990. Early expression of desmosomal components during kidney tubule morphogenesis in human and murine embryos. Development, vol. 108, no. 2, p. 313-321.

GILBERT, LI. and FRIEDEN, E., 1981. Metamorphosis: A Problem in Developmental Biology. New York: Ed. Plenum Press.

GOODRICH, ES., 1958. Studies on the structure and development of vertebrates. New York: Dover.

GUMBINER, B., STEVENSON, B. and GRIMALDI, A., 1988. The role of the cell adhesion molecule uvomorulin in the 
formation and maintenance of the epithelial junctional complex. J. Cell Biol., vol. 107, no. 4, p. 1575-1587.

HERRENKNECHT, K., OZAWA, M., ECKERSKORN, F., LOTTSPEICH, M., LENTNER, M. and KEMLER, R., 1991. The uvomorulin-anchorage protein $\alpha$-catenin is a vinculin homologue. Proc. Natl. Acad. Sci. USA, vol. 88, no. 20, p. $9156-9160$

HIRANO, S., NOSE, A., HATTA, K., KAWAKAMI, A. and TAKEICHI, M., 1987. Calcium-ependent cell-cell adhesion molecules (cadherins): subclass specificities and possible involvement of actin bundles. J. Cell Biol., vol. 105, no. 6 Pt 1, p. 2501-2510.

HOLTFRETER, J., 1931. Über die Aufzucht isolierter Teile des Amphibienkeimes. II Züchtung von Keimen und Keimteilen in Salzlösung. Wilhelm Roux Arch Entwicklungsmech. Org., vol. 124 , p. $405-464$.

IZAGUIRRE, MF., PERALTA SOLER, A. and CASCO, VH., 2000. Expression of NCAM-180 and N-cadherin during development in two south-american anuran species (Bufo arenarum and Hyla nana). Eur. J. Histochem., vol. 44, no. 4 , p. 407- 418 .

IZAGUIRRE, MF., PERALTA SOLER, A., LAJMANOVICH RC., and CASCO, VH., 2001a. $\alpha$-Catenin expression in the digestive tract of metamorphosing Hyla nana tadpoles (Anura: Hylidae): an immunohistochemical study. Amphibia-Reptilia, vol. 22 , p. $256-261$.

IZAGUIRRE, MF., ADUR, JF., PERALTA SOLER, A., and CASCO, VH., 2001b. Alterations induced by E-cadherin and $\beta$-catenin antibodies during the development of Bufo arenarum (Anura: Bufonidae). Histol. Histopathol., vol. 16, no. 4, p. $1097-1106$

KENDALL, EC., 1915. The isolation in crystalline form of the compound containing iodine which occurs in the thyroid: Its chemical nature and physiological activity. Trans. Assoc. Am. Phys., vol. 30, p. 420-449.

-, 1919. Physiological action of the thyroid hormone. Am. J. Physiol., vol. 49, p. 136-137.

KISPERT, A., VAINIO, S. and MCMAHON, AP., 1998. Wnt-4 is a mesenchymal signal for epithelial transformation of metanephric mesenchyme in the developing kidney. Development, vol. 125, no. 21, p. 4225-4234.

KLEIN, G., LANGEGGER, M., GORIDIS, C. and EKBLOM, P., 1988. Neural cell adhesion molecules during embryonic induction and development of the kidney. Development, vol. 102 , no. 4 , p. 749-761.

KNUDSEN, KA., PERALTA SOLER, A., JOHNSON, KR. and WHEELOCK, MJ., 1995. Interaction of $\alpha$-actinin with the cadherin/catenin cell-cell adhesion complex via $\alpha$-catenin. $J$. Cell Biol., vol. 130, no. 1, p. 67-77.

LACKIE, PM., ZUBER, C. and ROTH, J., 1990. Polysialic acid and N-CAM localization in embryonic rat kidney: mesenchymal and epithelial elements show different patterns of expression. Development, vol. 110, no. 3, p. 933-947.

LARUE, L., OHSUGI, M., HIRCHENHAIN, J. and KEMLER, R., 1994. E-cadherin null mutant embryos fail to form a trophectoderm epithelium. Proc. Natl. Acad. Sci. USA, vol. 91, no. 17 , p. $8263-8267$.
LASLETT, AL., LI, LH., JESTER Jr, WF. and ORTH, JM., 2000. Thyroid hormone down-regulates neural cell adhesion molecule expression and affects attachment of gonocytes in Sertoli cell-gonocyte cocultures. Endocrinology, vol. 141, no. 5 , p. $1633-1641$.

LELOUP, J. and BUSCAGLIA, M., 1977. La triiodothyronine: hormone de la métamorphose des amphibiens. C. R. Acad. Sci., vol. 284 , p. $2261-2263$

LEVI, G., BRODERS, F., DUNON, D., EDELMAN, GM. and THIERY, JP., 1990. Thyroxine-dependent modulations of the expression of the neural cell adhesion molecule N-CAM during Xenopus laevis metamorphosis. Development, vol. 108, no. 4, p. 681-692.

LUEGMAYR, E., GLANTSCHNIG, H., VARGA, F. and KLAUSHOFER K., 2000. The organization of adherens junctions in mouse osteoblast-like cells (MC3T3-E1) and their modulation by triiodothyronine and 1,25-dihydroxyvitamin D3. Histochem. Cell Biol., vol. 113, no. 6, p. 467-478.

MAKINO, Y., FUJII, T., KURODA, S., INENAGA, T., KAWANO, Y. and TAKISHITA, S., 2000. Exacerbation of renal failure due to hypothyroidism in a patient with ischemic nephropathy. Nephron, vol. 84, no. 3, p. 267-269.

MARTIN, MC., NUÑEZ, AM. and TOMATIS, ME., 1985. Metamorfosis en anfibios. I. Desarrollo metamórfico en larvas de Bufo arenarum Hensel (Amphibia: Anura). Hist. Nat., vol. 5, no. 32 , p. 289-302.

MCCREA, PD., TURCK, CW. and GUMBINER, B., 1991. A homolog of the armadillo protein in Drosophila (Plakoglobin) associated with E-cadherin. Science, vol. 254, no. 5036, p. 1359-61.

MIRANDA, LA., PISANÓ, A. and PAZ, DA., 1992. Effect of potassium perchlorate on thyroid activity of Bufo arenarum larvae. Com. Biol., vol. 10, p. 125-35.

MØBJERG, N., LARSEN, EH. and JESPERSEN, Å., 2000. Morphology of the kidney in larvae of Bufo viridis (Amphibia, Anura, Bufonidae). J. Morphol., vol. 245, no. 3, p. 177-195.

NAGAFUCHI, A. and TAKEICHI, M., 1989. Transmembrane control of cadherin-mediated cell adhesion: a $94 \mathrm{KDa}$ protein functionally associated with a specific region of the cytoplasmic domain of E-cadherin. Cell Regul., vol. 1, no. 1, p. 37-44.

NAGAFUCHI, A., TAKEICHI, M. and TSUKITA, S., 1991. The $102 \mathrm{kd}$ cadherinassociated protein: similarity to vinculin and posttranscriptional regulation of expression. Cell, vol. 65 , no. 5 , p. $849-857$.

NIEWKOOP, PD. and FABER, J., 1994. Normal Table of Xenopus laevis (Daudin). A systematical and chronological survey of the development from the fertilized egg till the end of metamorphosis. New York: John Gerhart and Marc Kirschner Garland Publishing Inc.

NOUWEN, EJ., DAUWE, S., VAN DER BIEST, I. and DE BROE, ME., 1993. Stage - and segment-specific expression of cell adhesion molecules N-CAM, A-CAM and L-CAM in the kidney. Kidney, vol. 44, no. 1, p. 147-158.

OZAWA, M., BARIBAULT, H. and KEMLER, R., 1989. The cytoplasmic domain of the cell adhesion molecule uvomorulin associates with three independent proteins structurally related in different species. EMBO J., vol. 8, no. 6, p. 1711-1717. 
PEIFER, M., MCCREA, PD., GREEN, KJ., WIESCHAUS, E. and GUMBINER, BM., 1992. The vertebrate adhesive junction proteins-catenin and plakoglobin and the Drosophila segment polarity gene armadillo form a multigene family with similar properties. J. Cell Biol., vol. 118, no. 3, p. 681-691.

PERANTONI, AO., 1999. Cell adhesion molecules in the kidney: from embryo to adult. Exp. Nephrol., vol. 7, no. 2, p. $80-102$.

PIEPENHAGEN, PA. and NELSON, WJ., 1993. Defining E-cadherin-associated protein complexes in epithelial cells: plakoglobin, $\beta$ - and $\gamma$-catenin are distinct components. J. Cell Sci., vol. 104, no. Pt 3, p. 751-62.

PROZIALECK, WC., LAMAR, PC. and APPELT, DM., 2004. Differential expression of E-cadherin, $\mathrm{N}$-cadherin and $\beta$-catenin in proximal and distal segments of the rat nephron. BMC Physiol., vol. 4, no. 1, p. 1-10.

POULIOT, Y., 1992. Phylogenetic analysis of the cadherin superfamily. BioEssays, vol. 14, no. 11, p. 743-748.

RENGEL, D., PAZ, D., PISANÓ, A. and PASINA, L., 1988. Developmental capacity of Bufo arenarum aged ovocytes. Microsc. Electron. Biol. Cel., vol. 10, p. 101-113.

RIETHMACHER, D., BRINKMANN, V. and BIRCHMEIER C., 1995. A targeted mutation in the mouse E-cadherin gene results in defective preimplantation development. Proc. Natl. Acad. Sci. USA, vol. 92, no. 3, p. 855-859.

RUGH, R., 1951. The Mesomere. The Pronephros or Head Kidney. The Mesonephros or Wolffian Body. In The frog. Its reproduction and development. USA: McGraw - Hill Book Company Inc. 336 p.

RUTISHAUSER, U., 1984. Developmental biology of a neural cell adhesion molecule. Nature, vol. 310, no. 5978, p. 549-554.

SAXÉN, L., 1987. Organogenesis of the Kidney. Developmental and cell biology series. Cambridge: Cambridge University Press.

SHAH, M., QUIGLEY, R. and BAUM, M., 2000. Maturation of proximal straight tubule $\mathrm{NaCl}$ transport: role of thyroid hormone. Am. J. Physiol. Renal Physiol., vol. 278, no. 4, p. 596-602

SHIMAZUI, T., OOSTERWIJK WAKKA, J., AKAZA, H., BRINGUIER, PP., RUIJTER, E., DEBRUYNE, FMJ., SCHALKEN, JA. and OOSTERWIJK, E., 2000. Alterations in expression of cadherin-6 and E-cadherin during kidney development and in renal cell carcinoma. Eur. Urol., vol. 38, no. 3 , p. $331-338$
STAPPERT, J. and KEMLER, R., 1993. Intracellular associations of adhesion molecules. Curr. Opin. Neurobiol., vol. 3 , no. 1 , p. 60-66.

STEARNS, SC., 1989. The evolutionary significance of phenotypic plasticity. Bioscience, vol. 39, p. 436-445.

SUZUKI, S. and SUZUKI, M., 1981. Changes in thyroidal and plasma iodine compounds during and after metamorphosis of the bullfrog, Rana catesbeiana. Gen Comp. Endocrinol., vol. 45 , no. 1 , p. $74-81$.

TAKEICHI, M., 1988. The cadherins: cell-cell adhesion molecules controlling animal morphogenesis. Development, vol. 102 , no. 4 , p. 639-655.

TAKEICHI, M., 1991. Cadherin cell adhesion receptors as a morphogenetic regulator. Science, vol. 251, no. 5000, p. 1451-1455.

TANI, T., LAITINEN, L., KANGAS, L., LEHTO, VP. and VIRTANEN, I., 1995. Expression of E- and N-cadherin in renal cell carcinomas, in renal cell carcinoma cell lines in vitro and in their xenografts. Int. J. Cancer, vol. 64, no. 6, p. 407-414.

TASSIN, MT., BEZIAU, A., GUBLER, MC. and BOYER, B. 1994. Spatiotemporal expression of molecules associated with junctional complexes during the in vivo maturation of renal podocytes. Int. J. Dev. Biol., vol. 38, no. 1, p. 45-54.

VESTWEBER, D., KEMLER, R. and EKBLOM, P., 1985. Cell adhesion molecule uvomorulin during kidney development. Dev. Biol., vol. 112, no. 1, p. 213-221.

WAHL, JK., SACCO, PA., MCGRANAHAN, TM., SAUPPÉ, L., WHEELOCK, MJ. and JOHNSON, KR., 1996. Plakoglobin domains that define its association with the desmosomal cadherins and the classical cadherins: identification of unique and shared domains. J. Cell Sci., vol. 109, no. Pt 5, p. 1043-1054.

WHEELOCK, MJ., KNUDSEN, KA. and JOHNSON, KR., 1996. Membrane cytoskeleton interactions with cadherin cell adhesion proteins: roles of catenins as linker proteins. Curr. Topics. Memb., vol. 43, p. 169-185.

WHITE, BA. and NICOLL, CS., 1981. Hormonal control of amphibian metamorphosis. In GILBERT, LI., FRIEDEN, E. (Eds.). Metamorphosis: A Problem in Developmental Biology. New York: Plenum Press. p. 363-396.

WU, JC., GREGORY, CW. and DEPHILIP, RM., 1993. P-cadherin and E-cadherin are co-expressed in MDCK cells. Biochem. Biophys. Res. Commun., vol. 195, no. 3, p. $1329-1335$. 